\title{
A wiggle-match date for Polynesian settlement of New Zealand
}

\author{
Alan G. Hogg, Thomas F.G. Higham, David J. Lowe, Jonathan G. \\ Palmer, Paula J. Reimer, \& Rewi M. Newnham*
}

Dating initial colonisation and environmental impacts by Polynesians in New Zealand is controversial. A key horizon is provided by the Kaharoa Tephra, deposited from an eruption of Mt Tarawera, because just underneath this layer are the first signs of forest clearance which imply human settlement. The authors used a log of celery pine from within Kaharoa deposits to derive a new precise date for the eruption via "wiggle-matching" - matching the radiocarbon dates of a sequence of samples from the log with the Southern Hemisphere calibration curve. The date obtained was $1314 \pm 12 \mathrm{AD}(2 \sigma$ error), and the first environmental impacts and human occupation are argued to have occurred in the previous 50 years, i.e. in the late $13^{\text {th }}$ - early $14^{\text {th }}$ centuries AD. This date is contemporary with earliest settlement dates determined from archaeological sites in the New Zealand archipelago.

Keywords: East Polynesia, New Zealand, Maori, dendrochronology, wiggle-matching,

${ }^{14} \mathrm{C}$ dating, colonisation, deforestation, tephrochronology, tephra, Kaharoa eruption

\section{Introduction}

New Zealand was the last substantial landmass to be colonised by humans before the industrial age. Although it is now well established that the Polynesian settlers of New Zealand originated in central East Polynesia (e.g. Penny et al. 2002), the date of such settlement has proved controversial. An early transient contact c. 50-150 AD, based on Pacific rat-bone (Rattus exulans) dates obtained from natural sites, was proposed by Holdaway $(1996,1999)$ and Holdaway \& Beavan (1999) on the premise that the rats, an introduced predator to New Zealand, accompanied the early Polynesians as a food source or stowaways (Roberts 1991; Matisoo-Smith et al. 1998). However, the reliability of the early rat-bone dates was disputed, especially as aberrant rat-bone dates were reported from several archaeological sites (Anderson 1996, 2000; Beavan \& Sparks 1998; Smith \& Anderson 1998; Hedges 2000; Higham \&

*Hogg, Waikato Radiocarbon Dating Laboratory, University of Waikato, Private Bag 3105, Hamilton, New Zealand. (Alan.Hogg@waikato.ac.nz)

Higham, Oxford Radiocarbon Accelerator Unit, Research Laboratory for Archaeology and the History of Art, University of Oxford, Oxford OX1 3QJ, England, U.K.

Lowe, Department of Earth Sciences, University of Waikato, Private Bag 3105, Hamilton, New Zealand.

Palmer, School of Archaeology and Palaeoecology, Queen's University of Belfast, Belfast BT7 1NN, Northern Ireland, U.K.

Reimer, Center for Accelerator Mass Spectrometry L-397, Lawrence Livermore National Laboratory, P.O. Box 808,

Livermore, California 94550, U.S.A.

Newnham, Department of Geographical Sciences, University of Plymouth, Plymouth PL4 8AA, England, U.K. 
Petchey 2000). Brook (2000) suggested, from dating predation damage of the landsnail Placostylus ambagiosus, that the Pacific rat probably became established in northernmost North Island at around the same time as permanent Polynesian settlement. Most recently, Holdaway et al. (2002) provided support for the early rat-bone dates, and suggested that the Pacific rat was present in New Zealand well before permanent Polynesian settlement.

Various authors have shown that there are no human archaeological contexts in New Zealand which pre-date the $12^{\text {th }}$ century AD (Anderson 1991; McFadgen 1994; McFadgen et al. 1994; Higham \& Hogg 1997; Higham et al. 1999). Recent archaeological and radiocarbon evidence now suggests strongly that the earliest settlers in the New Zealand archipelago arrived around c. 1250-1300 AD (McFadgen et al. 1994; Higham \& Hogg 1997; Higham et al. 1999). In addition, evidence from New Zealand's outlier islands (Norfolk, Kermadecs) supports the notion that southern Polynesia was all settled at virtually the same time in prehistory (Higham \& Johnson 1996; Anderson et al. 2001). This evidence supports the socalled 'late' settlement model first proposed by Anderson (1991).

\section{Dating environmental events}

Other dates for human settlement have been inferred from changes in environmental sequences. Short-lived, minor disturbances in the pollen record, including small increases in bracken (Pteridium esculentum) and other seral taxa, were attributed by Sutton $(1987,1994)$ to activities by a small but 'archaeologically invisible' population of early Polynesian colonists prior to $c .1300 \mathrm{AD}$. His interpretation forms the basis for the 'early' settlement model (Sutton 1987). However, critics have pointed out that such disturbances are indistinguishable from those resulting from natural background events, such as lightning-induced fires, impacts from volcanic eruptions, storms or droughts, and that these occurred throughout the Holocene with increasing frequency, and also in pre-Holocene pollen records (McGlone 1989; Wilmshurst et al. 1997; Ogden et al. 1998; Newnham et al. 1998a; McGlone \& Wilmshurst 1999).

McGlone \& Wilmshurst (1999) concluded that the first evidence for Polynesian environmental impact dates broadly to $c .1200-1400 \mathrm{AD}$ based on palynological data from many sites throughout New Zealand. A similar finding was reported by Ogden et al. (1998). Opal phytolith data from tephra-palaeosol sequences in the Bay of Plenty in eastern North Island are also consistent with these results (Kondo et al. 1994; Sase \& Hosono 1996), as are dunefield and sedimentological studies from northern and eastern North Island (McFadgen 1994; Wilmshurst 1997; Page \& Trustrum 1997; Brook 1999; Horrocks et al. 2001a) and also isotope analyses on speleothems in northern South Island (Hellstrom et al. 1998). Taken together, the palaeoenvironmental research suggests that deforestation, beginning in the period c. 1200-1400 AD, occurred virtually simultaneously across much of New Zealand. Exacting greater precision has been hampered because of the limitations of radiocarbon calibration allied with the uncertainty associated with identifying the first human deforestation signals (McGlone \& Wilmshurst 1999), and inadequate sampling resolution. Difficulties include the dating of recent events using radiocarbon where sediment contamination by in-washed carbon, in-built age, hard water or other factors may affect sample reliability (Elliot $e$ a al. 1997; Wilmshurst 1997; Wilmshurst et al. 1997; Newnham et al. 1998a, 1998b; McGlone \& Wilmshurst 1999; Lowe et al. in press). 


\section{Using tephrochronology}

To help resolve some of these problems, Newnham et al. (1998a) and Lowe et al. (2000, 2002) have promoted the role of tephrochronology - the use of tephra layers as marker beds to establish numerical or relative ages (Lowe \& Hunt 2001). This method provides a way of circumventing the interpretative difficulties associated with radiocarbon dating at palaeoenvironmental (natural) and archaeological sites because tephra layers provide virtually instantaneous chronostratigraphic marker horizons, or isochrons, that can be correlated between sites independently of radiometric dating. That tephra deposits are found in both natural and archaeological sites means they have the capacity for linking such sites in an unambiguous manner that no other dating or correlative technique can provide.

A key event for human prehistory in New Zealand is the eruption of the Kaharoa Tephra, a geochemically distinctive, rhyolitic tephra layer originating from $\mathrm{Mt}$ Tarawera volcano in the Okataina Volcanic Centre, North Island (Figure 1) (Lowe et al. 1998). Widely dispersed over at least $30,000 \mathrm{~km}^{2}$ of northern and eastern North Island, Kaharoa Tephra provides a unique 'settlement horizon' (landnám) for prehistory in northern New Zealand. Although no cultural artefacts are recorded beneath it (Anderson 1991; Shepherd et al. 1997; Lowe et al. 2000; Horrocks et al. 2001b), the earliest humaninduced environmental impacts, inferred largely from palynological data as described above, occur at around or just prior to its deposition (Newnham et al.

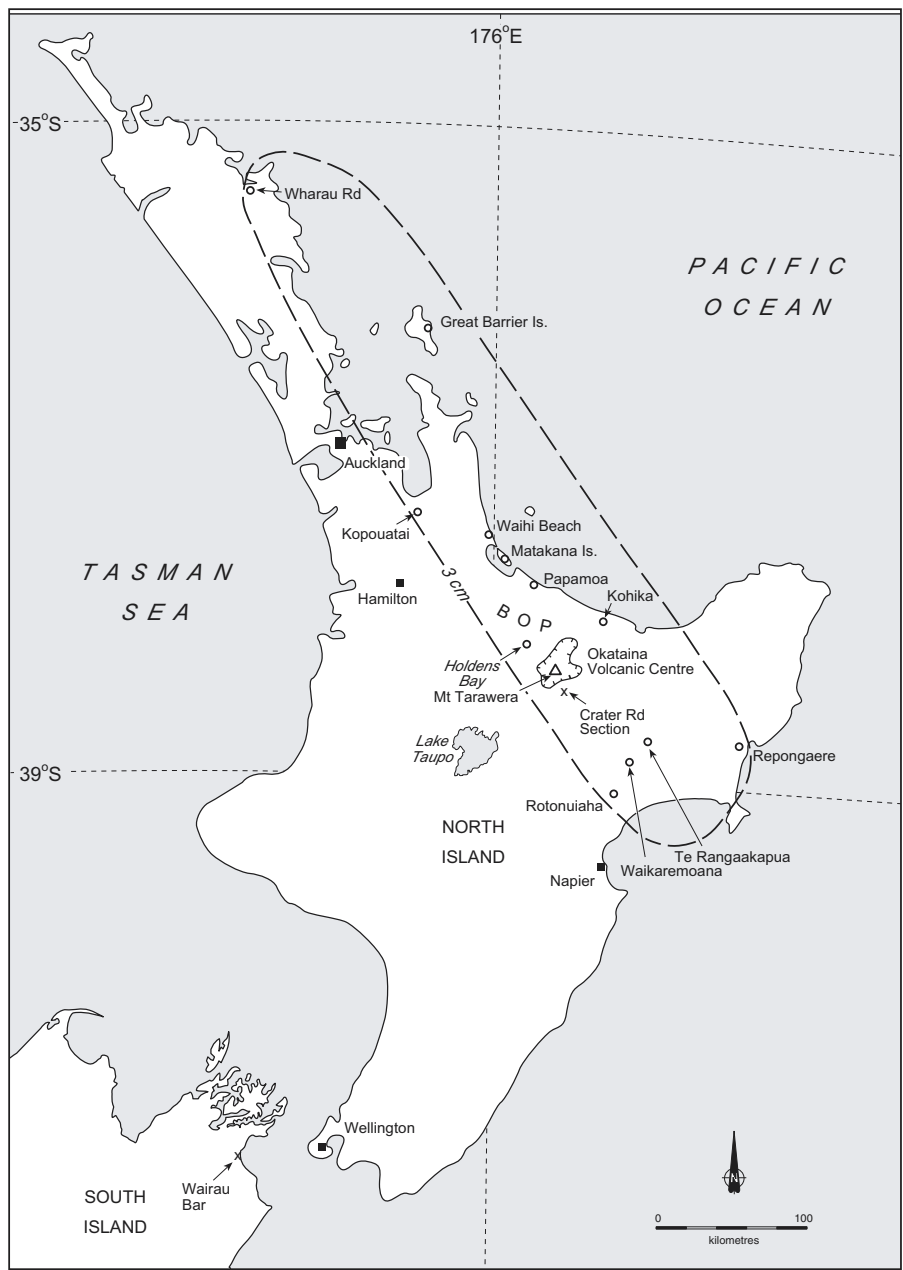

Figure 1. Locations of Crater Rd section (at metric grid reference V16/175197 on 1: 50,000 New Zealand Map Series 260) and Mt Tarawera massif (source of the Kaharoa Tephra), and pollen profiles (open circles) containing the Kaharoa datum and Polynesian deforestation signals (after Newnham et al. 1998a; additional data from Elliot et al. 1997; Horrocks et al. 2001b). Isopach after Lowe et al. (1998). BOP, Bay of Plenty. 1998a; Lowe et al. 2000). 


\section{Dating the Kaharoa Tephra}

Lowe et al. (1998) have determined a mean radiocarbon age for the deposition of the Kaharoa Tephra of $665 \pm 15$ radiocarbon years BP, but this corresponds to a wide range of calendar dates because of marked fluctuations of the calibration curves in the $14^{\text {th }}$ century. The date of the initial Polynesian deforestation signals has therefore remained ambiguous because the Kaharoa eruption could have occurred at any time between $c .1290 \mathrm{AD}$ and $c .1400 \mathrm{AD}$. This means initial settlement may have occurred towards the end of the $13^{\text {th }}$ century or more than a century later.

One method of achieving a more precise date for the Kaharoa eruption event, and thus a date for the earliest settlement, is by 'wigglematching' a known sequence of radiocarbon dates with the calibration curve. Samples taken from a known sequence, such as a tree ring series or superposed peat layers, are radiocarbon dated and the results fitted to the radiocarbon calibration curve using published statistical methods of best fit (Kojo et al. 1994; Christen \& Litton 1995; van der Plicht et al. 1995; van Geel et al. 1996; Kilian et al. 1995, 2000; Speranza et al. 2000). The 1000-year-long Southern Hemisphere calibration curve enabled us to apply wiggle-matching to provide high- resolution calendar dates without the need to account for possible variations in the offset between Northern Hemisphere calibration curves and dated material from the Antipodes (McCormac et al. 1998a, 1998b; Hogg et al. 2002).

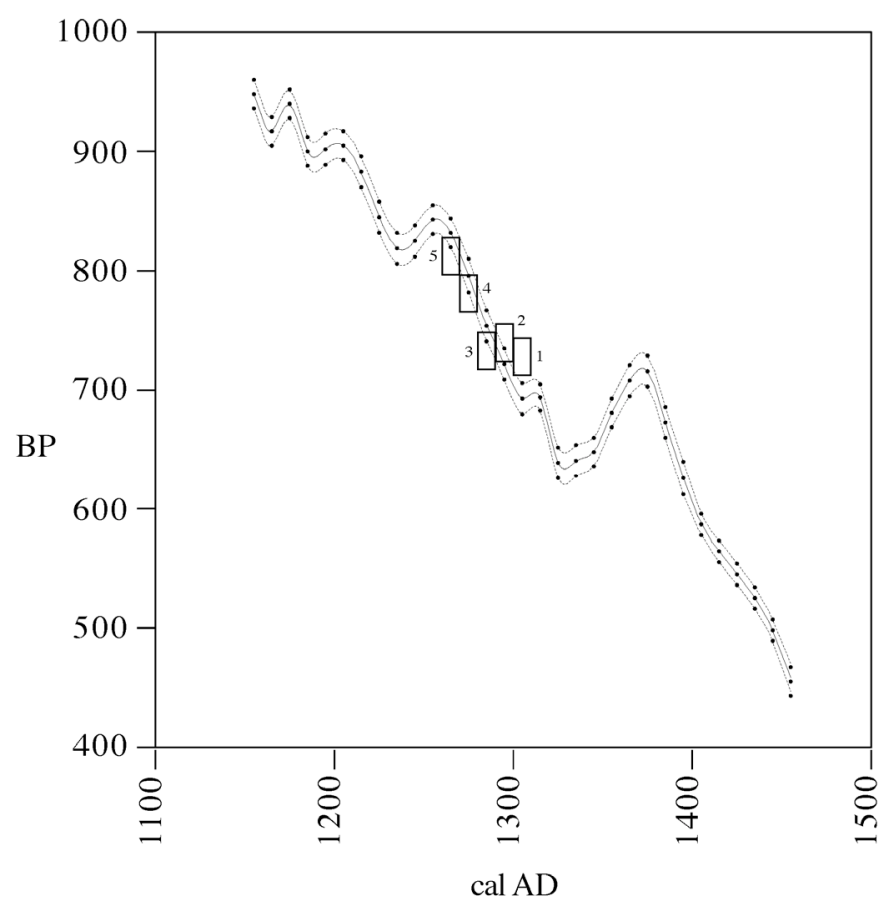

Figure 2. High-precision radiocarbon determinations (Table 1) on Phyllocladus spp. log samples fitted to the Southern Hemisphere terrestrial calibration curve (Hogg et al. 2002) for the period 1150-1450 AD.

The sequence of five radiocarbon measurements was wiggle matched to the calibration curve by minimizing the square of the sum of the differences between the calibration curve and the tree-ring data for each position along the calibration curve (Pearson 1986; van der Plicht et al. 1995):

$$
\mathrm{SS} \frac{\mathrm{n}}{\mathrm{i}=1}\left[\mathrm{BP}_{\mathrm{i}}(\text { curve })-\mathrm{BP}_{\mathrm{i}}(\text { date })\right]^{2}
$$

The uncertainty in the fit is calculated from the width of the SS distribution at the minimum value of $S S+S S / 2 N^{2}$ where $S S-S S / 2 N^{2}$ is below the minimum value and therefore not included.

We used the high-precision Southern Hemisphere calibration curve produced jointly by the University of Waikato and Queen's University of Belfast (McCormac et al. 1998a, 1998b; Hogg et al. 2002). The calibration curve is shown as a line enclosed within an envelope defined by $\pm 1 \sigma$ errors. The individual data points, plotted on the curve using best fit, are show as rectangles, with the width of the rectangle indicating the number of rings spanned by the sample (10 years) and the height of the rectangle indicating the sample standard error $( \pm 1 \sigma)$. 
We obtained a carbonised log, $0.15 \mathrm{~m}$ in diameter, with the bark intact, from within nearsource pyroclastic deposits (emplaced by hot, fast-moving, ground-hugging particulate gaseous flows) exposed at the Crater Rd section near Mt Tarawera (Figure 1). This section is a formally defined reference site (hypostratotype) for the Kaharoa Tephra Formation (see Froggatt $\&$ Lowe 1990 and Lowe et al. 1998, 2002 for details). The deposits ('unit Hpdc' in Nairn et al. 2001) encapsulating the log were emplaced early in the Kaharoa eruption episode. The duration of all the explosive eruption phases, which generated the distal tephra fall deposits ('Kaharoa Tephra'), is estimated at 'days to weeks' (Nairn et al. 2001). The log was identified as Phyllocladus spp., generally known as the celery pine. This genus is usually well suited to dendrochronology (Norton \& Palmer 1992; Newnham et al. 1999) and the rings proved suitable in our specimen. An inspection of the outermost ring revealed that it seemed to be completely formed, having both early wood and late wood. This suggests that the tree was killed during the period from late autumn to early spring (i.e. the period between growth cessation because of the onset of winter but before the start of spring growth). The exact month of the eruption within this period is impossible to determine, but our experience from contemporary tree-ring studies of the same species (e.g. Palmer et al. 1988) suggests that the period from May to September is likely.

Five contiguous ten-ring (i.e. decadal) blocks of carbonized wood were removed for highprecision radiocarbon dating. The first sample was the youngest, spanning ten annual rings obtained from the outside of the log, but excluding the bark. Subsequent samples were extracted contiguously towards the older, central part of the log. The methods and results of the radiocarbon analyses are given in Table 1, and Figure 2 shows the sequence of five dates, in their known order of age, matched to the wiggles of the high-precision Southern Hemisphere radiocarbon calibration curve.

The wiggle-matched date for the sample closest to the bark of the tree (Figure 2, no. 1) was $1308 \pm 12 \mathrm{AD}(2 \sigma$ error). However, a more accurate eruption date requires two other corrections. Firstly, five years must be added to each date because the ${ }^{14} \mathrm{C}$ determination represents the average of ten rings. A second correction, adding one year, is a dating convention used in the Southern Hemisphere (growth in the austral summer begins in one year and ends

Table 1. Radiocarbon measurements on carbonized Phyllocladus spp. log from Kaharoa eruptives, Crater $\mathrm{Rd}$. The carbonized wood samples of ten tree-rings each were pretreated by the standard acid-base-acid extraction procedure, with the $\mathrm{NaOH}$ step carried out in a nitrogen atmosphere to minimize the possibility of incorporation of modern carbon through absorption of atmospheric $\mathrm{CO}_{2} \cdot{ }^{14} \mathrm{C}$ was measured by liquid scintillation counting of benzene using a Wallac Quantulus 1220 spectrometer, especially optimized for high precision $\left( \pm 2-3 \% 0 ; \pm-16-24{ }^{14} \mathrm{C}\right.$ yr) measurements (Higham \& Hogg 1997; McCormac et al. 1998a, 1998b). Benzene samples $8.5 \mathrm{ml}$ in volume were counted for at least 7,500 minutes in Waikato $10 \mathrm{ml}$ synthetic silica counting vials (Hogg 1992).

\begin{tabular}{lccc}
\hline $\begin{array}{l}\text { Laboratory code } \\
(\text { Wk-) }\end{array}$ & $\begin{array}{c}{ }^{14} \mathrm{C} \text { age } \\
\text { (conventional yr BP) }\end{array}$ & $\begin{array}{c}\text { Sample number } \\
\text { (tree-rings number) }\end{array}$ & \\
\hline 8204 & $728 \pm 16$ & 1 & $(1-10:$ sapwood) \\
8205 & $740 \pm 16$ & 2 & $(11-20)$ \\
8206 & $733 \pm 16$ & 3 & $(21-30)$ \\
8207 & $780 \pm 16$ & 4 & $(31-40)$ \\
8208 & $812 \pm 16$ & 5 & $(41-50)$ \\
\hline
\end{tabular}


in the next), and so the calendar year for a tree-ring is reckoned as the year that the new growth began (Schulman 1956). The calendar date we have determined for the eruption of Kaharoa Tephra therefore is $1314 \pm 12$ AD (2o error).

For comparison, we also used $\mathrm{OxCal}$ to date the death of the tree by wiggle matching using a Bayesian approach (Ramsey 1995, OxCal 3.5; see also Ramsey et al. 2001). We used the D_Sequence model with ten-year gaps, and a six-year gap to account for the final tree rings (Figure 3A). The wiggle match produced a result for the death of the tree of 1310$1320 \mathrm{AD}(1 \sigma)$ and $1305-1325 \mathrm{AD}(2 \sigma)$ (Figure 3B). This finding is identical to that derived using the first method and adds confidence in our date for the eruption.

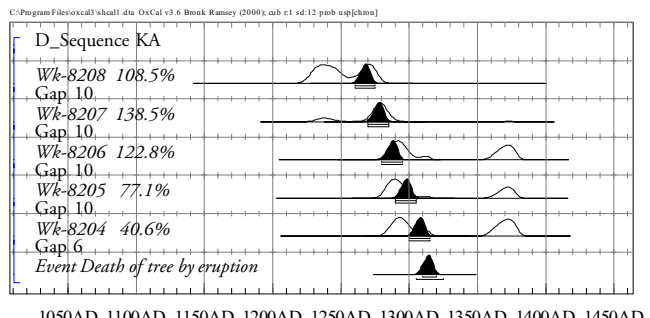

1050AD 1100AD 1150AD 1200AD 1250AD 1300AD 1350AD 1400AD 1450AD Calendar date

Figure 3. (A) Wiggle match obtained on Phyllocladus spp. log samples using OxCal 3.5 (Ramsey 1995, 2001) and the Southern Hemisphere terrestrial radiocarbon curve (Hogg et al. 2002). The agreement indices (A) indicate the extent to which the posterior distribution overlaps with the individual radiocarbon distributions (see Ramsey 2001), in a similar way to a chi-squared test. In the case of the Kaharoa Tephra wiggle match, the agreement index for the complete D_Sequence was $78.3 \%$, with $A n=31.6 \%(n=5)$, suggesting the overall fit is acceptable.

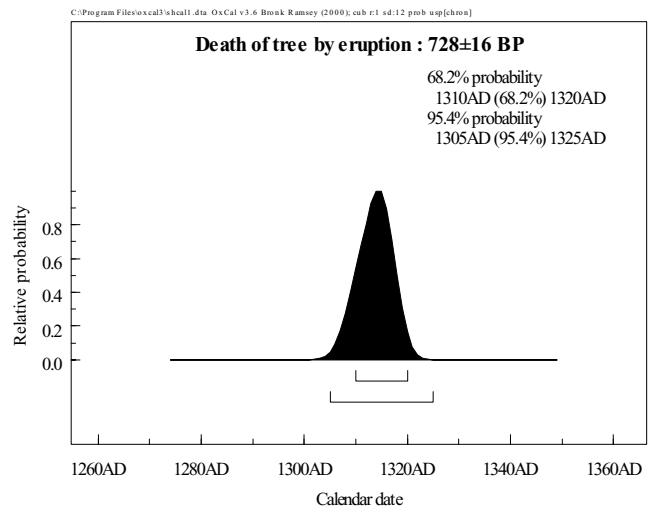

Figure 3. (B) The wiggle match shows that the tree was killed by the eruption between 1310-1320 AD (at 10) and 13051320 (at 20).

\section{Conclusion}

Establishing a precise calendar date for the Kaharoa Tephra, a key settlement layer in northern New Zealand, is important for investigating patterns and processes of prehistoric human colonisation in both New Zealand and East Polynesia and of its associated anthropogenic environmental impacts. More precise dates for human settlement aid in understanding the process and rate of cultural change, and the demography of human population growth rates from founding colonisers ( $c f$. Murray-Macintosh et al. 1998; Penny et al. 2002). We have

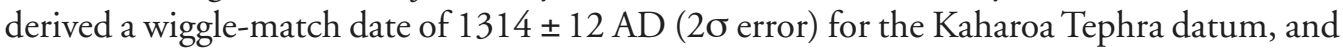
this acts as a settlement horizon for those areas where the tephra is known to occur in North Island. It remains possible of course that earlier sites await discovery outside the Kaharoa fallout zone.

Numerous archaeological sites in eastern and northern North Island have featured the Kaharoa Tephra (Lowe et al. 2000), and the absence of artefacts or cultural remains reported beneath it suggests that these sites must be younger than the wiggle-match date of $1314 \pm 12$ AD. Higham and Hogg (1997) showed that the earliest archaeological dates are indistinguishable in both main islands of New Zealand using radiocarbon, but because the 
Kaharoa Tephra is not currently traceable in the South Island, its use as a terminus ante quem for settlement is geographically circumscribed.

In the zone where it occurs, signals of environmental impact are essentially contemporary with or just pre-date the deposition of Kaharoa Tephra. Newnham et al. (1998a) examined eleven pollen profiles from peat or lacustrine deposits in northern and eastern North Island containing both Kaharoa Tephra and palynological indicators for the onset of significant deforestation (Figure 1). In the upper parts of pollen profiles, there are marked and sustained rises in bracken spores and charcoal, unprecedented in the Holocene record, and inferred to be the result of initial human firing (Newnham et al. 1998a; Lowe et al. 2000, 2002; Horrocks et al. 2001b). In a few profiles, the sustained rises in bracken and charcoal occur well after the Kaharoa Tephra datum but in the others the rises occur close to the time of its deposition. The earliest sustained rises begin in sediments only a few centimetres at most below the Kaharoa Tephra in four of the pollen profiles. Based on the chronostratigraphy of these profiles, all of which additionally contain the $232 \pm 15$ AD Taupo Tephra marker bed (Sparks et al. 1995; Lowe \& de Lange 2000), we consider that the amount of time represented by this pre-Kaharoa (bracken-bearing) sediment probably represents a maximum of about fifty years (Lowe et al. in press).

This suggests very strongly that the earliest environmental impacts associated with initial Polynesian settlement in northern New Zealand (North Island) occurred in the second half of the $13^{\text {th }}$ century AD, coincident with the earliest-known settlement dates from archaeological sites on both North Island and South Island.

\section{Acknowledgements}

We thank Ian Nairn for his help in sampling logs for dendrochronological evaluation and for information on the Kaharoa eruption, anonymous referees for their comments, and Martin Carver for his helpful editorial comments.

\section{References}

ANDERSON, A.J. 1991. The chronology of colonisation in New Zealand, Antiquity 65: 767-795.

Anderson, A.J. 1996. Was Rattus exulans in New Zealand 2000 years ago? AMS radiocarbon ages from Shag River Mouth, Archaeology in Oceania 31: 178-184.

Anderson, A.J. 2000. Differential reliability of ${ }^{14} \mathrm{C}$ AMS ages of Rattus exulans bone gelatine in south Pacific prehistory, Journal of the Royal Society of New Zealand 30: 243-261.

Anderson, A.J., T.F.G. Higham \& R.D. Wallace. 2001. The radiocarbon chronology of the Norfolk Island archaeological sites, in A.J. Anderson \& J.P. White (ed.), The Prehistoric Archaeology of Norfolk Island, Southwest Pacific. Records of the Australian Museum Supplement 27: 33-42. Sydney: Australian Museum.

Beavan, N.R. \& R.J. Sparks. 1998. Factors influencing ${ }^{14} \mathrm{C}$ ages of the Pacific rat Rattus exulans, Radiocarbon 40: 601-613.
BROOK, F.J. 1999. Stratigraphy, landsnail faunas, and palaeoenvironmental history of coastal dunefields at Te Werahi, northernmost New Zealand, Journal of the Royal Society of New Zealand 29: 361-393.

BRoOK, F.J. 2000. Prehistoric predation of the landsnail Placostylus ambagiosus Suter (Stylommatophora: Bulimulidae), and evidence for the timing of establishment of rats in northernmost New Zealand, Journal of the Royal Society of New Zealand 30: 227-241.

Christen, J.A. \& C.D. LitTon. 1995. A Bayesianapproach to wiggle-matching,-Journal of Archaeological Science 22: 719-725.

Elliot, M.B., B. Striewski, J.R. Flenley, J.H. Kirkman \& D.G. SutTon. 1997. A 4300 year palynological record of environmental change and human impact from Wharau Road swamp, Northland, New Zealand, Journal of the Royal Society of New Zealand 27: 401-418.

FrogGatT, P.C. \& D.J. Lowe. 1990. A review of late Quaternary silicic and some other tephra formations from New Zealand: their stratigraphy, nomenclature, distribution, volume, and age, New Zealand Journal of Geology and Geophysics 33: 88-99. 


\section{A wiggle-match date for Polynesian settlement of New Zealand}

Hedges, R.E.M. 2000. Appraisal of radiocarbon dating of kiore bones (Pacific rat Rattus exulans) in New Zealand, Journal of the Royal Society of New Zealand 30: 385-398.

Hellstrom, J., M. Mcculloch \& J. Stone. 1998. A detailed 31,000-year record of climate and vegetation change from the isotope geochemistry of two New Zealand speleothems, Quaternary Research 50:167-178.

Higham, T.F.G. \& A.G. Hogg. 1997. Evidence for late Polynesian colonisation of New Zealand: University of Waikato radiocarbon measurements, Radiocarbon 39: 149-192.

Higham, T.F.G. \& L. Johnson. 1996. The prehistoric chronology of Raoul Island, the Kermadec Group, Archaeology in Oceania 31: 207-213.

Higham, T.F.G. \& F.J. Petchey. 2000. On the reliability of archaeological rat bone for radiocarbon dating in New Zealand, Journal of the Royal Society of New Zealand 30: 399-409.

Higham, T.F.G., A.J. Anderson \& C. Jacomb. 1999. Dating the first New Zealanders: the chronology of Wairau Bar, Antiquity 73: 420-427.

Hogg, A.G. 1992. Performance and design of 0.3-ml to $10-\mathrm{ml}$ synthetic silica liquid scintillation vials for low-level- ${ }^{14} \mathrm{C}$ determination, Radiocarbon 34: 135-142.

Hogg, A.G., F.G. Mccormac, T.F.G. Higham, P.J. Reimer, M.G.L. Baillie, J.G. Palmer \& M. STUIVER. 2002. High-precision ${ }^{14} \mathrm{C}$ measurements of contemporaneous tree-ring dated wood from the British Isles and New Zealand: AD 1850 - 950, Radiocarbon 44(3) in press

Holdaway, R.N. 1996. Arrival of rats in New Zealand, Nature 384: 225-226.

HoldaWAY, R.N. 1999. A spatio-temporal model for the invasion of the New Zealand archipelago by the Pacific rat Rattus exulans, Journal of the Royal Society of New Zealand 29: 91-105.

Holdaway, R.N. \& N.R. Beavan. 1999. Reliable ${ }^{14} \mathrm{C}$ AMS dates on bird and Pacific rat Rattus exulans bone gelatin, from a $\mathrm{CaCO}_{3}$-rich deposit, Journal of the Royal Society of New Zealand 29: 185-211.

Holdaway, R.N., R.G. RoberTs, N.R. BEAVANAthfield, J.M. Olley \& T.H. Worthy. 2002. Optical dating of quartz sediments and accelerator mass spectrometry ${ }^{14} \mathrm{C}$ dating of bone gelatin and moa eggshell: a comparison of age estimates for non-archaeological deposits in New Zealand, Journal of the Royal Society of New Zealand 32: 463-505.

Horrocks, M., S.L. Nichol, M.R. Gregory, R. Creese \& P.C. Augustinus. 2001a. A Holocene pollen and sediment record of Whangape Harbour, far northern New Zealand, Journal of the Royal Society of New Zealand 31: 411-424.
Horrocks, M., Y. Deng, J. Ogden, B.V. Alloway, S. Nichol \& D.G. SutTon. 2001b. High spatial resolution of pollen and charcoal in relation to the c. 600 year BP Kaharoa Tephra: implications for Polynesian settlement of Great Barrier Island New Zealand, Journal of Archaeological Science 28: 153168.

Kilian, M.R., J. Van Der Plicht \& B. Van Geel. 1995. Dating raised bogs: new 14C AMS wiggle matching, a reservoir effect and climatic change, Quaternary Science Reviews 14: 959-966.

Kilian, M.R., B. Van Geel \& J. Van Der Plicht. 2000. 14C AMS wiggle matching raised bog deposits and models of peat accumulation, Quaternary Science Reviews 19: 1011-1033.

Kojo, Y., R.M. Kalin \& A. Long. 1994. Highprecision wiggle-matching in radiocarbon dating, Journal of Archaeological Science 21: 475-479.

Kondo, R., C.W. Childs \& I. AtKinson. 1994. Opal Phytoliths in New Zealand. Lincoln: Manaaki Whenua Press.

Lowe, D.J. \& W.P. De Lange. 2000. Volcanometeorological tsunamis, the c. AD 200 Taupo eruption (New Zealand) and the possibility of a global tsunami, The Holocene 10: 401-407.

LOWE, D.J. \& J.B. Hunt. 2001. A summary of terminology used in tephra-related studies, in E.T. Juvigné \& J-P. Raynal (ed.), 'Tephras: Chronology, Archaeology'. Les dossiers de l'Archaéo-Logis 1: 1722. Goudet (France): CDERAD.

Lowe, D.J., B.G. Mcfadgen, T.F.G. Higham, A.G. HogG, P.C. Froggatt \& I.A. Nairn. 1998. Radiocarbon age of the Kaharoa Tephra, a key marker for late-Holocene stratigraphy and archaeology in New Zealand, The Holocene 8: 499507.

Lowe, D.J., R.M. Newnham, B.G. McFadgen \& T.F.G. Higham. 2000. Tephras and New Zealand archaeology, Journal of Archaeological Science 27: 859-870.

Lowe, D.J., R.M. Newnham \& J.D. Mccraw. 2002. Volcanism and early Maori society in New Zealand, in R. Torrence \& J. Grattan (ed.), Natural Disasters and Cultural Change: 126-161. London: Routledge.

Lowe, D.J., R.M. Newnham, T.F.G. Higham, J.M. Wilmshurst, M.S. Mcglone \& A.G. HogG. in press. Dating earliest human impact and settlement in New Zealand, in D.G. Sutton (ed.), Origins of the First New Zealanders 2 nd edition. Auckland: Auckland University Press.

Matisoo-Smith, E., R.M. Roberts, G.J. Irwin, J.S. Allen, D. Penny \& D.M. Lambert. 1998. Patterns of prehistoric human mobility in Polynesia indicated by mtDNA from the Pacific rat, Proceedings of the National Academy of Sciences USA 95: 15145-15150. 
Mccormac, F.G., A.G. Hogg, T.F.G. Higham, M.G.L. Baillie, J.G. Palmer, L. Xiong, J.R. Pilcher, D. Brown \& S.T. HOPER. 1998a. Variations of radiocarbon in tree-rings: Southern Hemisphere offset preliminary results, Radiocarbon 40: 11531159.

Mccormac, F.G., A.G. Hogg, T.F.G. Higham, J. Lynch-Steiglitz, W.S. Broecker, M.G.L. Baillie, J.G. Palmer, L. Xiong, J.R. Pilcher, D. Brown \& S.T. Hoper. 1998b. Temporal variation in the interhemispheric ${ }^{14} \mathrm{C}$ offset, Geophysical Research Letters 25: 1321-1324.

McFadgen, B.G. 1994. Coastal stratigraphic evidence for human settlement, in D.G. Sutton (ed.), Origins of the First New Zealanders: 195-207. Auckland: Auckland University Press.

Mcfadgen, B.G., F.B. Knox \& T.R.L. Cole. $1994 .{ }^{14} \mathrm{C}$ calibration curve variations and their implications for the interpretation of New Zealand prehistory, Radiocarbon 36: 221-236.

Mcglone, M.S. 1989. The Polynesian settlement of New Zealand in relation to environmental and biotic changes, New Zealand Journal of Ecology (Supplement) 12: 115-129.

McGlone, M.S. \& J.M. Wilmshurst. 1999. Dating initial Maori environmental impact in New Zealand, Quaternary International 59: 5-16.

Murray-Macintosh, R.P., B.J. Scrimshaw, P.J. Hatfield \& D. Penny. 1998. Testing migration patterns and estimating founding population size in Polynesian by using human mtDNA sequences, Proceedings of the National Academy of Sciences, USA 95: 9047-9052.

Nairn, I.A., S. Self, J.W. Cole, G.S. LeOnard \& C. SCUTTER. 2001. Distribution, stratigraphy, and history of proximal deposits from the c. AD 1305 Kaharoa eruptive episode at Tarawera volcano, New Zealand, New Zealand Journal of Geology and Geophysics 44: 467-484.

Newnham, R.M., D.J. Lowe, M.S. Mcglone, J.M. Wilmshurst \& T.F.G. Higham. 1998a. The Kaharoa Tephra as a critical datum for earliest human impact in northern New Zealand, Journal of Archaeological Science 25: 533-544.

Newnham, R.M., D.J. Lowe \& B.W. MatThews. 1998b. A late Holocene and prehistoric record of environmental change from Lake Waikaremoana, New Zealand, The Holocene 8: 443-454.

Newnham, R.M., D.J. Lowe \& P.W. Williams. 1999. Quaternary environmental change in New Zealand: a review, Progress in Physical Geography 23: 567-610.

Norton, D.A., \& J.G. Palmer. 1992. Dendroclimatic evidence from Australasia, in R.S. Bradely \& P.D. Jones (ed.), Climate Since AD 1500: 463-482. London: Routledge.
Ogden, J., L.R. Basher \& M.S. Mcglone. 1998. Fire, forest regeneration and links with early human habitation: evidence from New Zealand, Annals of Botany 81: 687-696.

Page, M.J. \& N.A. Trustrum. 1997. A late Holocene lake sediment record of the erosion response to land use change in a steepland catchment, New Zealand, Zeistschrift für Geomorphologie 41: 369392.

Palmer, J.G., J. Ogden \& R.N. Patel. 1988. A 426year floating tree-ring chronology from Phyllocladus trichomanoides buried by the Taupo eruption at Pureora, central North Island, New Zealand, Journal of the Royal Society of New Zealand 18: 407-415.

Pearson, G.W. 1986. Precise calendrical dating of known growth-period samples using a 'curve fitting' technique, Radiocarbon 28: 292-299.

Penny, D., R. Murray-Mcintosh \& G.L. Harrison. 2002. Estimating the number of females in the founding population of New Zealand: analysis of mtDNA variation, Journal of the Polynesian Society 111: 207-221.

Ramsey, C.B. 1995. Radiocarbon calibration and analysis of stratigraphy: the OxCal program, Radiocarbon 37: 425-430.

Ramsey, C.B. 2001. Development of the radiocarbon calibration programme, Radiocarbon 43: 355-363.

Ramsey, C.B., J. Van Der Plicht \& B. Weninger. 2001. 'Wiggle matching' radiocarbon dates, Radiocarbon 43: 381-389.

RoberTs, M. 1991. Origin, dispersal routes, and geographic distribution of Rattus exulans, with special reference to New Zealand, Pacific Science 45: 123-130.

Sase, T. \& M. Hosono. 1996. Vegetation histories of Holocene volcanic ash soils in Japan and New Zealand - relationship between genesis of melanic volcanic ash soils and human impact, Earth Science (Chikyu Kagaku) 50: 66-82.

Schulman, E. 1956. Dendroclimatic Changes in Semiarid America. Tucson: University of Arizona Press.

Shepherd, M.J., B.G. Mcfadgen, H.D. Betts \& D.G. SuTTON. 1997. Formation, landforms and palaeoenvironment of Matakana Island and implications for archaeology, Science and Research Series 102. Wellington: Department of Conservation.

Smith, I.W.G. \& A.J. ANDERSON. 1998. Radiocarbon dates from archaeological rat bones: the Pleasant River case, Archaeology in Oceania 33: 88-91.

Sparks, R.J., W.H. Melhuish, J.W.A. Mckee, J. Ogden \& J.G. Palmer. $1995 .{ }^{14} \mathrm{C}$ calibration in the Southern Hemisphere and the date of the last Taupo eruption: evidence from tree-ring sequences, Radiocarbon 37: 155-163. 


\section{A wiggle-match date for Polynesian settlement of New Zealand}

Speranza, A., J. Van Der Plicht \& B. Van Geel. 2000. Improving the time control of the Subboreal/Subatlantic transition in a Czech peat sequence by C-14 wiggle-matching, Quaternary Science Reviews 19: 1589-1604.

SutTon, D.G. 1987. A paradigmatic shift in Polynesian prehistory: implications for New Zealand, New Zealand Journal of Archaeology 9: 135-155.

SuTton, D.G. 1994. Conclusions: origins, in D.G. Sutton (ed.), Origins of the First New Zealanders: 243-258. Auckland: Auckland University Press.

Van Der Plicht, J., E. Jansma \& H. Kars. 1995. The "Amsterdam Castle": a case study of wiggle matching and the proper calibration curve, Radiocarbon 37: 965-968.
Van Geel, B., J. Buurman \& H.T. Waterbolk. 1996. Archaeological and palaeoecological indications of an abrupt climate change in The Netherlands, and evidence for climatological teleconnections around 2650 BP, Journal of Quaternary Science 11: 451460.

Wilmshurst, J.M. 1997. The impact of human settlement on vegetation and soil stability in Hawke's Bay, New Zealand, New Zealand Journal of Botany 35: 97-111.

Wilmshurst, J.M., M.S. Mcglone \& T.R. Partridge 1997. A late Holocene history of natural disturbance in lowland podocarp/hardwood forest, Hawke's Bay, New Zealand, New Zealand Journal of Botany 35: 79-96. 